\title{
CZU: 581.1:541.459:674.031.189 \\ https://doi.org/10.53040/gppb7.2021.23 \\ ACTIVITATEA PROCESELOR FS II ŞI REDOX LA FRUNZELE DE CIMIŞIR DE VÂRSTE DIFERITE CA INDICATORI AI REZISTENŢEI LOR LA ŞOCUL CU TEMPERATURI NEGATIVE
}

\author{
Ralea Tudor, Zdioruk Nina, Platovschii Nicolai \\ Institutul de Genetică, Fiziologie şi Protecţie a Plantelor, Chişinău, Republica Moldova \\ e-mail: zdioruc-nina@mail.ru
}

\begin{abstract}
The resistance of annual and biennial leaves of boxwood to the effects of negative temperatures has been studied. The parameters of PS II activity and the parameters of the redox potential were determined in different periods after exposure to shock at temperatures of $-5^{\circ} \mathrm{C},-10^{\circ} \mathrm{C},-15^{\circ} \mathrm{C}$ and $-20^{\circ} \mathrm{C}$. It was shown that the stability and ability to recover from damage caused by shock at different temperatures, were higher in annual leaves compared to biennial leaves.

Key words: Boxwood leaves (Buxus sempervirens L.), shock negative temperatures (SNT), seasonal and age variation, Photosystem II (PS II).

\section{Introducere}

Cimişirul este una din plantele decorative utilizate pe larg pentru înverzire [1]. Capacitatea cimişirului de aşi păstra frunzele verzi pe întreaga durată a anului, sugerează că el este o plantă ce posedă un înalt potenţial de rezistenţă şi adaptare la condiţiile sezoniere ale anului. Datorită proprietăţilor menţionate cimişirul poate servi ca plantă model în studierea multiplilor procese fiziologice şi biochimice ce depind de condiţiile specifice a fiecărui anotimp. Luând aceasta în consideraţie, noi am studiat rezistenţa frunzelor de cimişir la acţiune şocului cu temperaturi negative (ŞTN) în diferite anotimpuri ale amului.
\end{abstract}

\section{Materiale şi metode}

Frunzele de cimişir au fost colectate iarna, când temperatura aerului ziua era de $-6^{\circ} \mathrm{C}-10^{\circ} \mathrm{C}$ iar noapte $-10^{\circ}-15^{\circ} \mathrm{C}$ şi se menţinea aproximativ la aceiaşi parametri nu mai puţin de cinci zile consecutive. Aceste temperaturi sunt cel mai des atestate în raionul Chişinăului în perioada iernii. Lotul de frunze colectat de pe lăstarii anuali şi cei de doi ani a fost menţinut în frigider la temperatura de $-6-8^{\circ} \mathrm{C}$, în saci de polietilenă, fără contactului lor cu pereţii frigiderului.

În continuare frunzele au servit drept material experimental pentru aprecierea acţiunii ŞTN. Ca martor au servit frunzele transferate de la condiţiile de păstrare la temperatura de $4^{\circ} \mathrm{C}$ timp de 60 min, perioadă de păstrare necesară pentru ca frunzele să-şi restabilească elasticitatea. Apoi, ele au fost transferate pe durata a 30 min la lumina tuburilor luminiscente (RFA $50-55 \mu$ мол. $\mathrm{m}^{-2} \mathrm{~s}^{-}$) şi temperatura $+10+15^{\circ} \mathrm{C}$. Frunzele variantelor experimentale au fost transferate direct de la condiţiile de păstrare a lotului la acţiunea ŞTN timp de 24 ore. După această perioadă, cu fluorimetru PAM-2100 (Germania), la frunzele martor şi cele experimentale a fost apreciat cuantumul efectiv al FS II (Yield) [2].

Pentru aprecierea profunzimii dereglărilor provocate FS II de ŞTN, frunzele martor şi cele experimentale au fost menţinute în condiţii identice în termostat la $\mathrm{T}=22-24^{\circ} \mathrm{C}$, lumina cu RFA $50-55$ $\mu$ тол. $\mathrm{m}^{-2} \mathrm{~s}^{-1}$ şi fotoperioada de 16 ore - lumină şi 8 ore întuneric; umiditatea relativă a aerului de 95 97\%. Aprecierea intensităţii procesului de restabilire a viabilităţii aparatului fotosintetic şi a activităţii enzimelor a fost efectuat concomitent la frunzele martor şi celor expuse ŞTN pe durata experienţei.

Atât profunzimea modificărilor induse FS II cât şi intensitatea procesului de restabilire a lor, au fost apreciate după valoarea cuantumului efectiv al FS II iar activitatea sumară a fermenţilor utilizatori de $\mathrm{H}_{2} \mathrm{O}_{2}$, - cu analizatorul YSI 5300A (CШA).

\section{Rezultate şi discuţii}

Aprecierea acţiunii ŞTN asupra funç̧ionării aparatului fotosintetic şi activităţii enzimelor a fost efectuat prin mărirea treptată a valorilor temperaturilor negative asupra frunzelor colectate în perioada de iarnă. A fost determinată doza limită a ŞTN ca temperatura care la durata de expunere 8 ore a dus la diminuarea a activităţii FS II până la zero. În acest caz dereglările induse FS II de ŞTN au fost foarte grave, fiind incompatibile cu viabilitatea frunzelor. 
Iniţial a fost studiată acţiunea ŞTN cu temperatura $-5^{\circ} \mathrm{C}$ asupra frunzelor colectate iarna. Cercetările au demonstrat că după expunerea lor la această temperatură activitatea FS II practic nu era afectată, deci şocul cu $5^{\circ} \mathrm{C}$ nu a provocat dereglări esenţiale în derularea proceselor fiziologice şi biochimice în frunzele experimentale. Restabilirea dereglărilor induse de ŞTN a fost rapidă, datorită la ce eficacitatea FS II în perioadă relativ scurtă s-a egalat cu cea caracteristică pentru frunzele martor. Scăderea temperaturii şocului până la $-10^{\circ} \mathrm{C}$ a indus dereglări mai profunde iar restabilirea acestora a avut loc pe parcursul a 9 zile de la expunerea la ŞTN (Figura 1).

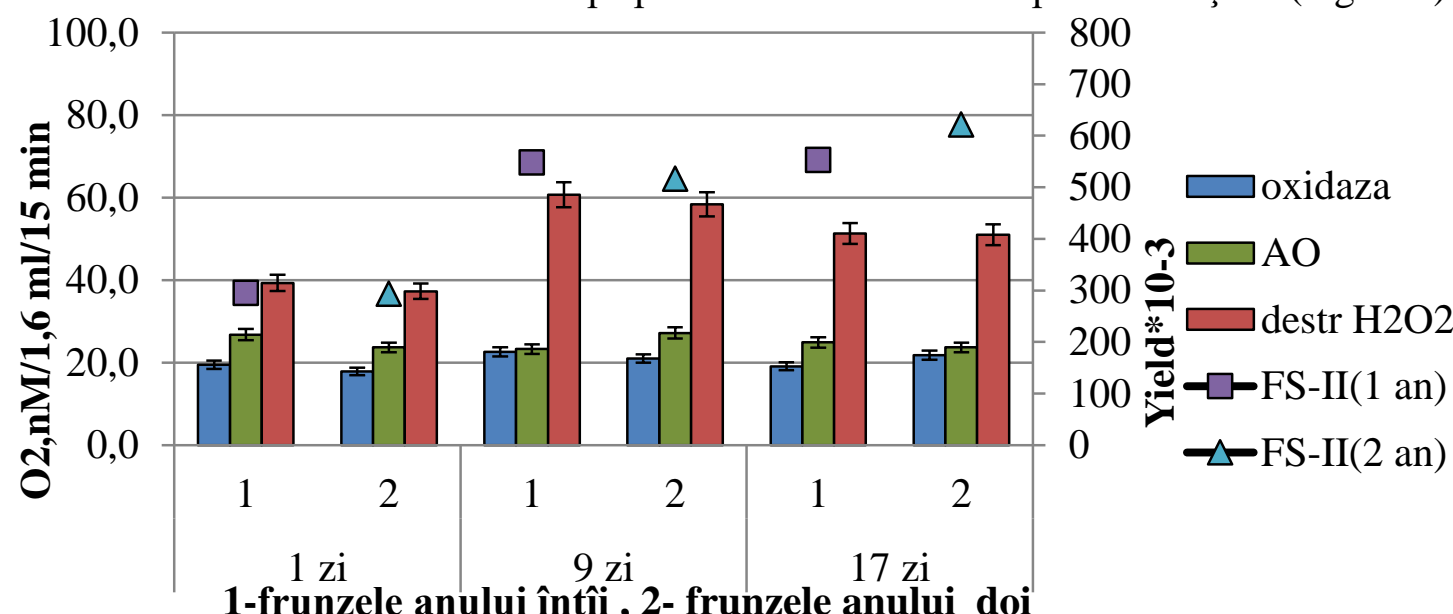

Figura 1. Influenţa şocului cu temperatura $-10^{\circ} \mathrm{C}$ asupra activităţii enzimelor oxido-reductive în extracte şi a valorilor Yeld a FS-II a frunzelor de cimişir, prelevate pentru analiză iarna.

Rezultatele prezentate în figura 1 demonstrează că intensitatea procesului de restabilire a FS II la frunzele în vârsta de un an era mai mare faţă de cel la frunzelor de doi ani. Această legitate se păstrează pe întreaga durată a procesului de restabilire după acţiune ŞTN. Concomitent cu restabilirea activităţii FS II a avut loc şi sporirea activităţii enzimelor consumătoare de $\mathrm{H}_{2} \mathrm{O}_{2}$, pe când activitatea oxidazei şi antioxidanţilor era mult mai mică şi rămânea practic constantă în perioada de restabilire

Şocul cu temperatura $-15^{\circ} \mathrm{C}$ induce în frunze modificări substanţiale care se caracterizează prin micşorarea substanţială a activităţii FS II (Figura 2).

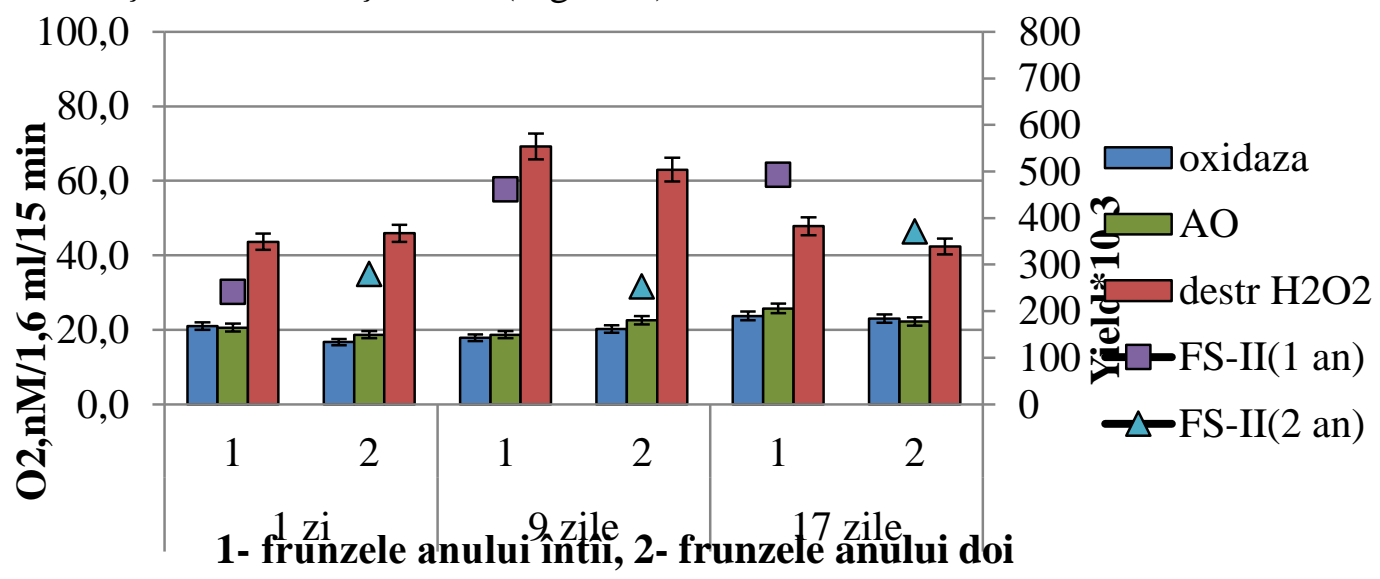

Figura 2. Influenţa şocului cu temperatura $-15^{\circ} \mathrm{C}$ asupra activităţii enzimelor oxido-reductive în extracte şi a valorilor Yeld a FS-II a frunzelor de cimişir, prelevate pentru analiză iarna.

Datele prezentate în figura 2 demonstrează că în primele nouă zile a perioadei de restabilire a deteriorărilor provocate de ŞTN are loc atât creşterea consumului de oxigen, cât şi restabilirea activităţii FS II, intensitatea proceselor fiind mai mare în frunzele în vârsta de un an. Din figura 2 se vede că după nouă zile de la expunerea la STN procesele de restabilire au devenit mai lente iar după 17 zile, intensitatea activităţii FS II în frunzele în vârsta de un an au atins doar 50 \% a valorii acesteia în frunzele martor. Rezultatele obţinute demonstrează faptul că temperatura $-15^{\circ} \mathrm{C}$ induce atât dereglări incompatibile cu viabilitatea frunzelor, cât şi dereglări care se restabilesc parţial, sau total, în perioada de restabilire. Datele prezentate permit să presupunem că şocul cu $-15^{\circ} \mathrm{C}$ caracterizează temperatura limită ce provoacă trecerea 
frunzelor la o stare de imposibilitate de restabilire a homeostazei, deci această temperatură poate fi considerată drept temperatură critică pentru viabilitatea frunzelor.

Sporirea temperaturii ŞTN până la $-20^{\circ} \mathrm{C}$ a indus dereglări esenţiale în derularea proceselor fotosintetice şi enzimatice în frunzele de cimişir (Figura 3). Despre aceasta putem concluziona din faptul că chiar după 17 zile de la aplicarea ŞTN a fost atestată doar o creştere nesemnificativă a activităţii FS II şi a micşorării consumului de oxigen de la 53-55 până la 5-10 nM. În acelaşi timp valorile iniţiale înalte a activităţii oxidazei şi AO servesc drept argument în favoarea derulării intense a proceselor distructive în frunze, induse de ŞTN.

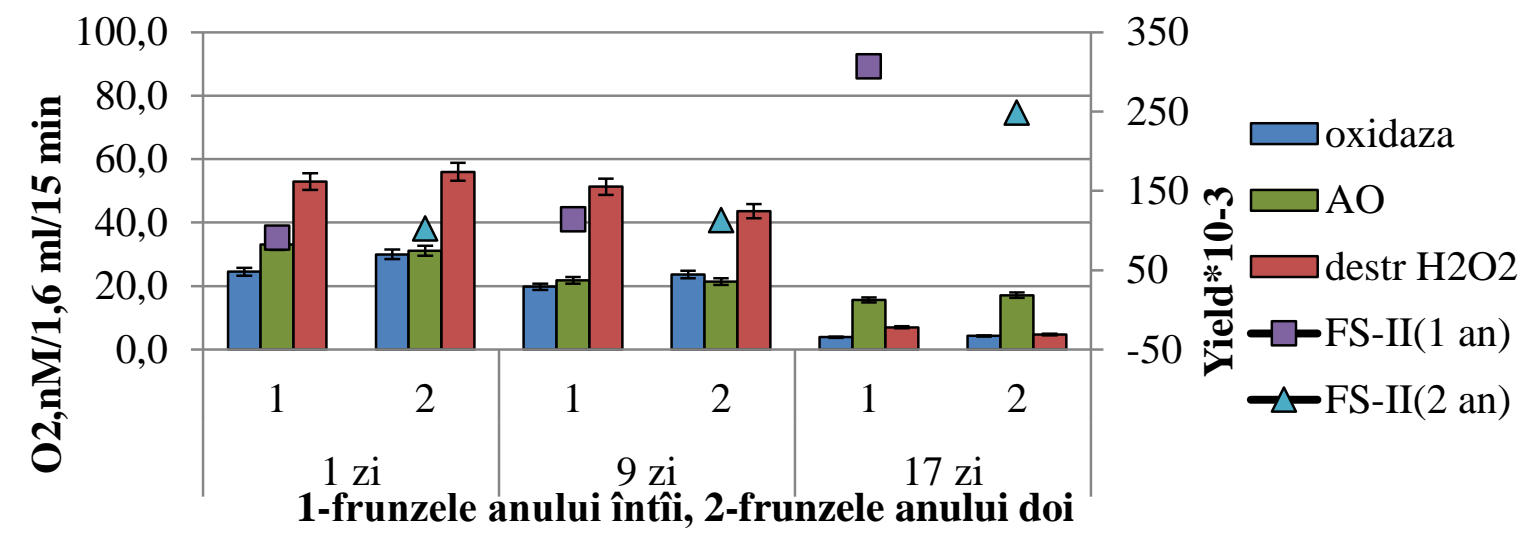

Figura 3. Influenţa şocului cu temperatura $-20^{\circ} \mathrm{C}$ asupra activităţii enzimelor oxido-reductive în extracte şi a valorilor Yeld a FS-II a frunzelor de cimişir, prelevate pentru analiză iarna

Aplicarea asupra frunzelor de cimişir a ŞTN de $-25^{\circ} \mathrm{C}$ provoacă dereglări incompatibile cu viabilitatea frunzelor şi se reflectă substanţial asupra derulării tuturor proceselor fiziologice şi biochimice din ele (Figura 4). Frunzele expuse acţiunii ŞTN de $-25^{\circ} \mathrm{C}$ şi transferate la restabilire în condiţii normale, la scurt timp după expunere îşi pierd culoarea şi devin brune, fapt ce demonstrează vizual gravitatea modificărilor provocate de ŞTN.



Figura 4. Influenţa şocului cu temperatura $-25^{\circ} \mathrm{C}$ asupra activităţii enzimelor oxido-reductive în extracte şi a valorilor Yeld a FS-II a frunzelor de cimişir, prelevate pentru analiză iarna

\section{Concluzii}

Frunzele de cimişir colectate iarna posedă o rezistenţă înaltă la acţiunea ŞTN, temperatura limită de restabilire a deteriorărilor fiind egală $\mathrm{cu}-15^{\circ} \mathrm{C}$.

Rrezistenţa frunzelor de cimişir la acţiunea ŞTN este cu atât mai înaltă cu cât frunzele sunt mai tinere.

Cercetările au fost realizate în cadrul proiectului Programului de Stat 20.80009.7007.07 „Determinarea parametrilor ce caracterizează rezistența plantelor cu nivel diferit de organizare la acțiunea temperaturilor extreme în scopul diminuării efectelor schimbărilor climatice”, finanţat de Agenția Naţională pentru Cercetare și Dezvoltare.

\section{Bibliografie}

1. Энциклопедический словарь Брокгауза и Ефрона: в 86 т. (82 т. и 4 доп.).- СПб., 1890-1907.

2. DASCALIUC, A., RALEA,T., CUZA, P. Influence of heat shock on chlorophyll fluorescence of white oak (Quercus pubescens Winilld.) leaves//Photosintetica//45(3): 469-471,2007. 